\title{
Populism, Nationalism, and Nationalist Populism
}

\author{
Prerna Singh ${ }^{1}$
}

Accepted: 5 May 2021 / Published online: 3 July 2021

(C) The Author(s), under exclusive licence to Springer Science+Business Media, LLC, part of Springer Nature 2021

\begin{abstract}
This article builds an original, analytical framework to understand one of the most important developments of our times - the global ascendance of leaders who fuse populist anti-elite rhetoric with nationalist appeals. In contrast to arguments that treat populism and nationalism as either completely separate or essentially equivalent phenomena, I begin from an understanding of the two as distinct ideologies that grow from a shared foundational claim to represent an "us" versus a "them." In part 1, I first juxtapose populism and nationalism around this common, undergirding us-them boundary to bring out their core features. I then analyze how populism and nationalism vary across the twin axes of intensity and inclusiveness to bring out their distinct sub-types. In part 2, I use this theoretical map of populism and nationalism to navigate the conceptual terrain of their intersection. I focus, in particular, on the implications of nationalist populism for those seen as "us" versus those viewed as "them," where the "us" and "them" are determined by the dimensions of intensity and inclusiveness. In contrast to characterizations of nationalist populism in directional terms as negative, I suggest that it is instead better understood as an amplifying force that exacerbates both the positive and negative consequences of populism. All else equal, relative to populism, those beyond nationalist populist boundaries are subject to heightened hostility and discrimination, while those within benefit from enhanced life opportunities.
\end{abstract}

\section{Introduction}

Whether it is Bolsonaro in Brazil, Modi in India, or Trump in the USA, in some of the largest countries in the world have risen leaders who fuse populist anti-elite rhetoric with nationalist appeals. Many of these regimes have been associated with racism, xenophobia, discrimination, and violence against minorities. This global wave of "nationalist populism" has churned much ferment across popular and scholarly

Prerna Singh

prerna_singh@brown.edu

1 Brown University, Providence, RI, USA 
circles. From this have arisen two prominent sets of arguments: first, the conceptualization of populism and nationalism either as essentially equivalent or as entirely distinct phenomena and, second, the consequences of the intersection of populism and nationalism, and indeed often of each individually, as inherently destructive.

This article pushes against both these sets of arguments. In part 1, I put forward an original conceptual framework for understanding populism and nationalism that begins from an understanding of the two as distinct ideologies that connect through their shared claim to represent an "us" as distinct from a "them." In part 1a, I juxtapose populism and nationalism around this common, foundational us-them boundary to bring out their core features. Then in part $1 \mathrm{~b}, \mathrm{I}$ analyze how populism and nationalism vary across the twin axes of intensity and inclusiveness. From this analysis emerge subgenuses of populism and nationalism, which in turn bring into view consequences, including but also beyond the discrimination and hostility towards ethnic minorities that both are dominantly associated with.

In part 2, I draw on this theoretical map of populism and nationalism to navigate the conceptual terrain of their intersection. I focus on the implications for "us" and "them," where the "us" and "them" are determined by the dimensions of intensity and inclusiveness. Against characterizations of nationalist populism in directional terms as negative, I suggest that it is better understood a tailwind. Ceteris paribus, relative to populism, those beyond nationalist populist boundaries are subject to heightened hostility and discrimination, while those within benefit from enhanced life opportunities.

\section{Part 1: What Are Populism and Nationalism?}

Much popular writing around their coterminous rise treats populism and nationalism as equivalent phenomena (Fukuyama 2018; Landler 2019; Pfeffer 2017). Some scholars have responded to this conflation by drawing a sharp definitional distinction between the two (De Cleen 2019), at the root of which often lies a normative preference for either populism or nationalism. Scholars arrive at a "pure" definition of their preferred concept and push morally problematic cases to the other category. Stavrakakis et al. (2017) and Katsambekis and Stavrakakis (2017), for example, argue that by their definition, Europe's anti-immigrant parties are fundamentally nationalist and not really populist. But Müller (2019) suggests that leaders such as Orbán, Modi, and Trump are not nationalists so much as "populist poseurs."

I push back against this sundering of populism and nationalism. Instead, building on, but also moving beyond scholars such as Brubaker (2019), Bonikowski et al. (2019), de la Torre (2017), and Jenne (2018), I chart an original analytical map that brings out populism and nationalism as overlapping but analytically distinct phenomena. In as much as populism and nationalism are both ideologies that rest on a claim to represent an "us"- "the people," populism is distinguished by its discursive, stylistic repertoire. It is usually not attributed with any fixed aims beyond the disruption associated with its aggressive oral, written, as well as visual, and performative 
style of communication (Kenny 2017; Moffitt 2016). ${ }^{1}$ In contrast, at the definitional core of nationalism is a purpose. It is not associated with any specific tactical style, so much as the aim to secure and/or shore up attachment to a self-governing territory. Populism and nationalism can manifest and accordingly have been studied in terms of different forms. As summarized in Table 1 and will be discussed further later, individuals, leaders, movements, and political parties are relevant units of analysis for both, and nationalism can also be analyzed at the level of state institutions. I will be focusing, in this article, for the most part on the populism and nationalism of established nation-states.

\section{Part 1a: The Common Conceptual Core of Populism and Nationalism: An Us-Them Boundary}

At the heart of both populism and nationalism beats a boundary - between those who belong to "the people" they claim to represent and those who do not. This usthem distinction is the core of the conceptual kinship between populism and nationalism and also arguably of their (mistaken) conflation. It is also a fertile site for teasing out the resonances and tensions between the two concepts, as summarized in Table 1.

\section{How Is the Us-Them Boundary Configured in Populism and Nationalism?}

Populism as an ideology is rooted in a claim to represent a moral community. The defining feature of populism's "us" is that they are simple, virtuous "people" who are distinguished from a venal, self-interested elite, who control the levers of sociopolitical power. In contrast, by its most influential formulation, the nation is an "imagined community" that has or seeks sovereign control of a historic homeland. Nationalism is accordingly an aspiration for and/or allegiance to such a national political community (Anderson 1991). The outgroup for nations is, by definition, other nations. Because the nation, especially in its present Westphalian marriage with the state, is a territorial identity, the out-group takes on a literal meaning. Those beyond the geographic boundaries of established nation-states are also usually outside its boundaries of belonging, seen as part of alternate claims to nationhood, and distinct systems of political, socio-economic rights and obligations. ${ }^{2}$

If these are the broad contours of the "us" and "them," a follow-up question is who represents the "us"? Populism and nationalism are, as noted in Table 1, ideologies that manifest across different levels. But across all mobilizations, populisms tend to be more personalized. The "cult of the leader" (de la Torre 2017; Moffitt 2016) looms large in, and by the accounts of some scholars is constitutive of, populism in a way

\footnotetext{
1 Inter alia for definitions that see populism beyond a stylistic repertoire, see Varshney (2019a), Abts and Rummens (2007), and Jaffrelot and Tillin (2017.

2 A clear exception is those who leave their country of origin but retain citizenship and/or allegiance to their native countries. But even with unprecedented mobility, only $3 \%$ of the world's population lives outside the country where they were born.
} 


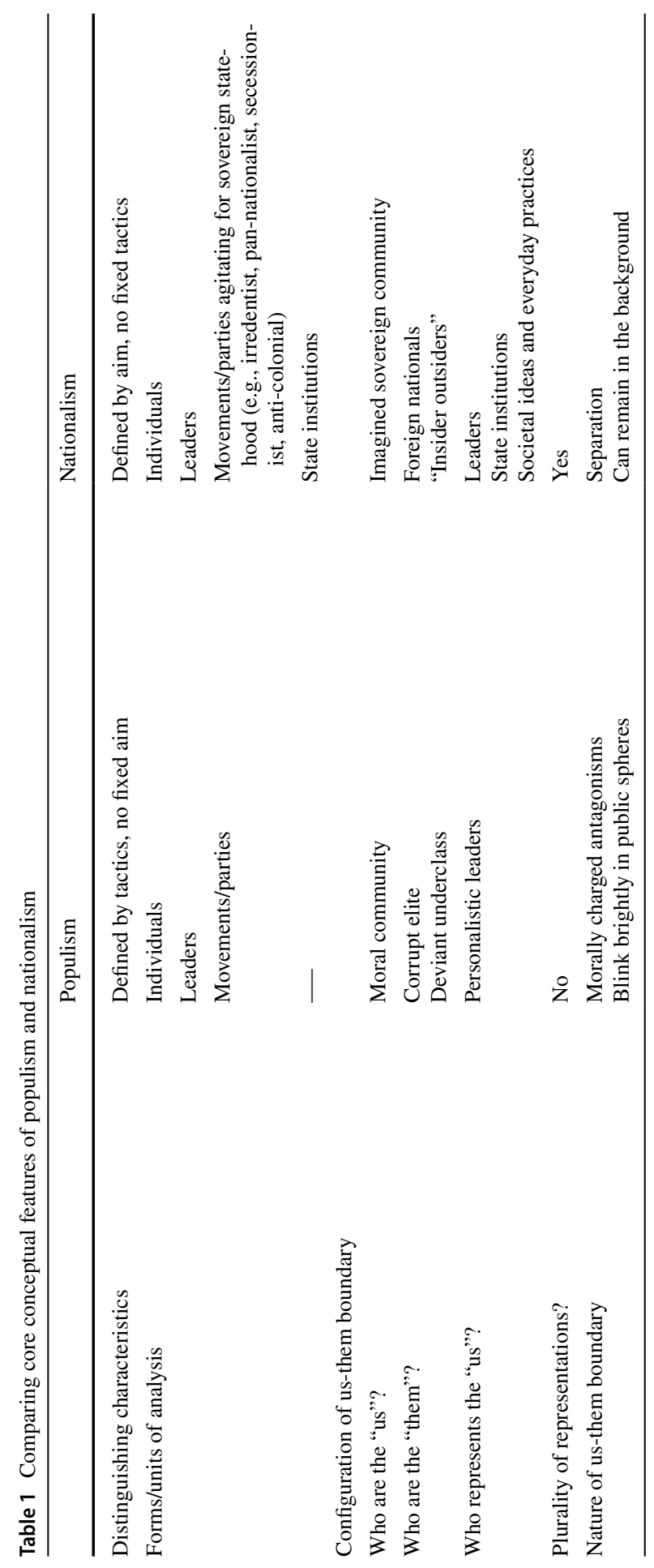


that it is not for nationalism. In as much as populism is seen as a transgressive style of communication, it is embodied by populist leaders. Described as charismatic, "maverick" outsiders, populist leaders have "bad manners" (Moffitt 2016: 44), their "vulgar" behavior (Mastropaolo 2008: 32) driving the likening of populism to a drunk guest at a dinner party (Arditi 2007: 78). Populist leaders claim a close, unmediated relationship to, and indeed often present themselves as embodiments of "the people." As such, they claim to be the sole spokespeople for "the people" (Müller 2016; Filc 2010; Mudde and Rovira Kaltwasser 2013).

In contrast, nationalism as a concept scripts a far less leading role for its leaders. Leaders certainly play an important role in nationalist movements and parties (Hroch 2000). They are often the public faces of the nation. They can exercise considerable jurisdiction over the demarcation of the boundaries of the nation, especially at critical junctures of a state's foundation. But unlike populism, nationalist leaders' representations of the nation co-exist and sometimes compete, on the one hand, with those enshrined in state institutions such as national constitutions, censuses, and maps, and on the other hand, with societal, everyday representations of the nation.

\section{Nature of the Us-Them Boundary in Populism and Nationalism}

Moving on from its definition to its configuration, all else equal, the us-them boundary is more likely to be a site for conflict in populism vis-à-vis nationalism. This is because, unlike nationalism, the populist boundary bristles with a moral charge. Elites, and also, as will be discussed later, potentially an underclass, are not only outside populism's "people"; they are in Schmittian terms, the enemies of the people (Mudde and Rovira Kaltwasser 2013; Bonikowski et al. 2019; Canovan 1999). The infusion of virtue further serves as a license for, even necessitates, an indignant, vehemence, and righteous shrillness in populists' broadcasting of this Manichean, good vs evil duality. Populism's us-them boundary is inherently bellicose, and it blinks brightly, even blindingly, in the public sphere.

In contrast, nationalism's in-out boundary need neither be conflictual nor conspicuous. Nationalism's "others" are outsiders — set apart and often unequal, but not necessarily the subjects of hostility. Attachment to and positive attitudes towards fellow nationals do not imply antipathy towards those not seen to belong to the nation (Mummendey et al. 2001; Sniderman et al. 2004; Huddy 2013; Doob 1964; Kosterman and Feshbach 1989) ${ }^{3}$. Foundational texts on nationalism echo this association with in-group positivity rather than out-group negativity (Anderson 1991; Mill 1991).

\footnotetext{
3 These studies build on social psychological research that shows that attitudes towards one's in-group can be associated with varied reciprocal attitudes towards outgroups, ranging from mild positivity, indifference, contempt, to hostility (Brewer 1979). In-group love does not require outgroup hate.

4 JS. Mill famously contrasted nationalism with "a senseless antipathy to foreigners" describing it instead as "a principle of sympathy, not of hostility; of union; not of separation." Similarly, writing 140 years later, Benedict Anderson countered the idea that nationalism is rooted "in fear and hatred of the Other," connecting it instead to "love." "The cultural products of nationalism," Anderson pointed out, "poetry, prose fiction, music, plastic arts - show this love very clearly in thousands of different forms and styles. On the other hand, how truly rare is it to find analogous nationalist products expressing fear and loathing?" (1991: 141-142).
} 
This is by no means to suggest that the us-them boundary in nationalism cannot be a site of conflict. History brims with examples of nationalist violence, even genocide, far bloodier than anything that can be chalked up to populism. Within nationalism, certain forms, such as those actively mobilizing for sovereign statehood, can tend towards more strained relations with their opponents.

Nationalist boundaries can also become visible and charged during nationalist celebrations, sports, and heightened inter-state rivalries. But nationalism's boundaries can equally operate in an innocuous, understated fashion, through its embeddedness in state institutions, as well as in everyday "banal" practices "endemic" to modern cultural and political life (Billig 1995; Goode and Stroup 2015; Skey 2011; Brubaker 1996: 10). ${ }^{5}$

In sum, populism is always "hot" - it operates purely in a mobilizational register, and its boundary is by definition, an antagonistic frontier. Nationalism, on the other hand, can also exist "cold" (Fox and Miller-Idriss 2008; Skey 2011; Brubaker et al. 2018). Its separations only become schisms under certain conditions (Brewer 1979). Inasmuch as it has historically been associated with bloody conflicts, it can also operate on a quotidian basis as a background frame of idioms and practices.

\section{Part 1b: Twin Dimensions of Populism and Nationalism: Intensity and Inclusiveness}

The previous section compared populism and nationalism around their shared usthem boundary to bring out their core analytical features. In this section, I show how populism and nationalism vary around the twin axes of intensity and inclusiveness. This allows us to distinguish different types of populism and nationalism and, in doing so, understand and move beyond their popular characterizations as inherently pernicious phenomena.

\section{Intensity}

The starting point for thinking about the intensity of populism and nationalism is that neither is a binary phenomenon. Instead, they are best seen as matters of degree (Gidron and Bonikowski 2013; Hawkins 2009; Deegan-Krause and Haughton 2009). Indeed, assessments of their intensity, conceptualized as their adherence to the ideological positions associated with, occupy an important place in the scholarship on populism and nationalism.

Several scholars have, for instance, looked at "populist attitudes" among voters (Oliver and Rahn 2016; Akkerman et al. 2014). Other studies have deployed a battery of content analysis techniques on speeches of leaders (Hawkins 2009; Armony and Armony 2005), manifestoes and other documents associated with populist movements and parties (Pauwels 2011; Jagers and Walgrave 2007; Caiani and

\footnotetext{
5 Jones and Merriman (2009), however, use the debate around bilingual road signs in Wales to push against and blur Billig's distinction between banal and "hot" nationalism.
} 
Graziano 2016), and/or conducted comparative case studies to capture the strength of their populist discourse (Deegan-Krause and Haughton 2009). Within the scholarship on nationalism, there is a growth industry of studies using attitudinal surveys to capture individuals' national attachments (Dekker et al. 2003; Bonikowski and DiMaggio 2016; Lieberman and Singh 2012). Analogous to the studies on populism, content and case analyses have sought to assess the intensity of nationalist movements and parties (Halikiopoulou and Vlandas 2019).

However, in addition to the degree to which they are espoused as ideologies, we may additionally think of the intensity of populism and nationalism in terms of the extent of their potential impact. This can in turn be seen as a product of their access to political power. Following Mudde and Kaltwasser (2012: 209), we anticipate that populist and nationalist parties are most likely to be able to implement their vision if they win elections and hold office. ${ }^{6}$ Political parties that adhere strongly to the ideologies and participate in government thus represent the most intense of populisms and nationalisms.

\section{Inclusion}

Insofar as, both populism and nationalism are fundamentally about boundaries, a certain amount of exclusion is at the crux of both concepts. However, populists and nationalists also exclude beyond their definitional "thems." Exclusion beyond these definitional "thems" is also a subordination.

Populism's pure, hardworking people are set apart not only from a morally corrupt elite on top, but also potentially, from a deviant underclass, depicted as "parasites" or "spongers" (Brubaker 2019). Similarly, nationalism's boundary separates not only those associated with other nations, but also the so-called "insider outsiders." As "second-class citizens," nationalism's "insider outsiders" are placed in an unequal hierarchical position to "true," prototypical citizens (Theiss-Morse 2009; Wimmer 2013). The dimension of inclusion focuses on these groups that depending on specific historical, geographical, and demographic characteristics can be seen as having subordinate status because of, or some combination of, ethnicity, language, race, religion, indigeneity, class, occupation, sexuality, or immigrant status.

This question of the inclusion of subordinate groups lies at the core of important dichotomies in the scholarship on both populism and nationalism. In the former, it is critical to the distinction between inclusionary and exclusionary populisms (Mudde and Kaltwasser 2013; Filc 2015; Font et al. 2021). For nationalism, it is implicit in the separation into voluntary, liberal civic nationalism that emphasizes freedom, tolerance, equality, and individual and minority rights, as distinct from atavistic, illiberal ethnic nationalism that is seen as hostile to minorities. Widespread critiques, however, have prompted a move away from this normatively problematic

\footnotetext{
${ }_{6}$ However, inasmuch as scholars argue that populists' participation in government prompts a "mainstreaming" and a "toning down" of their populism, we can anticipate a hydraulic relationship between these two approaches to the intensity of populism (Deegan-Krause and Haughton 2009, Mény and Surel 2002).
} 
and empirically fraught exercise of sorting nationalisms into these arbitrary, artificial categories (Brubaker 1996). Instead, scholars are increasingly approaching nationalism as a unified phenomenon that can be assessed in terms of how inclusive it is of different groups, notably minorities and/or immigrants (Schulte and Singh 2020; Tudor and Slater 2020; Kymlicka 1995; Tamir 1995).

What does it mean for populism and nationalism to be inclusive? For populism, the most influential conceptualization is that of Mudde and Kaltwasser (2013) who, following Filc (2010), analyze it across three interrelated dimensions - symbolic, material, and political. ${ }^{7}$ The inclusiveness of nationalism can be understood in ideational terms, through popular attitudes, school textbooks, popular media, and other public representations of who is/should be a member of the nation, and in institutional terms, by examining the extent to which state institutions discriminate against members of particular groups (Schulte and Singh 2020). ${ }^{8}$

What determines the inclusion of ethnic and other minorities in populism and nationalism is an important question that requires careful attention to temporal and regional patterns, particular histories, socio-political and cultural trajectories, and demographics of states. But reflective of both as "thin ideologies" their inclusiveness can be linked to their association with host ideologies. For populism, this has most prominently been left and right ideologies. ${ }^{9}$ This underlies Mudde and Kaltwasser's (2013) influential separation of regional subtypes of inclusive Latin American and exclusive Western European populism. Left populists in Latin America define the "us" in economic terms. "The people" are the working class and the poor pitted against a rapacious, exploitative elite who are "leeching off" their hard work. ${ }^{10}$ But economic deprivation does not exist in a vacuum. It overlaps with other forms of marginality - ethnic, gender, occupational, regional, and institutional. This intersectionality means that, contingent on a diverse demography, left populists' working class "us" are likely to include linguistic, racial, religious, indigenous, sexual, and other minorities, those from stigmatized occupations and migrants. On the other hand, right populists in Europe frame the "ordinary," "decent" people in cultural-ethnic terms, as religious, ethnic, or racial majorities pitted against a cultural elite - who are distant from and fail to back the cultural concerns of the ethnic majority (Brubaker 2019: 11). Prominently excluded from the nation are various ethnic minorities — racial, religious, linguistic, and indigenous — but also potentially sexual and other minorities. The

\footnotetext{
7 My discussion of the inclusiveness of populism towards subordinate groups corresponds to Mudde and Rovira Kaltwasser's (2013) first dimension of symbolic inclusion.

8 This is related to and draws on Bloemraad et al.'s (2019) delineation of national inclusion in legal, social and cultural terms. It is important to note that Bloemraad et al. (2019) are explicit that these different types of inclusion need not all go together.

9 Other ideological categorizations of populism include agrarian populism (Jaffrelot and Tillin 2017; Kazin 1998), American Southern segregationism (Gidron and Bonikowski 2013), and the malleable antiinstitutionalism of the Five Star Movement (Font et al. 2021).

${ }^{10}$ For left-leaning populists the enemies have varied across bankers, corporations, global financial systems such as Bretton Woods, neoliberalism, imperialist countries of the Global North, notably the USA, international organizations such as the World Bank and the IMF, and also, recently the EU.
} 
Table 2 Typology of populism and nationalism by variation in intensity and inclusiveness

\begin{tabular}{lll}
\hline & Less intense & More intense \\
\hline Less inclusive & Regressive potential & $\begin{array}{l}\text { More regressive potential: } \\
\text { Likely to be associated with prejudice, xenophobia, discrimina- } \\
\text { tion, and conflict }\end{array}$ \\
& & $\begin{array}{l}\text { More progressive potential: } \\
\text { Likely to be associated with projects of increasing membership } \\
\text { and socio-economic and political opportunities for minorities }\end{array}$ \\
& & Progressive potential \\
& &
\end{tabular}

left-right ideological space is present but less prominent in discussions of the inclusiveness of nationalism (Halikiopoulou et al. 2012; Brubaker 2017). Instead whether nationalism is based on more mutable attributes and thus inclusive of minorities and/or immigrants is linked to their association with related ideologies such as liberalism (Tamir 1995; Gustavsson and Miller 2020), multiculturalism (Kymlicka and Banting 2006), or pluralism (Castles 2010; Favell 2016; Miller 1995a).

The intensity and inclusiveness of populism and nationalism are dynamic and vary across each of the units they manifest in, over time. Analyzing particular spatial-temporal manifestations of populism and nationalism in terms of these twin dimensions allows us to identify distinct sub-types, depicted in Table 2. Such a typology in turn helps us understand the dominant negative reputations of populism and nationalism. When Pope Francis condemns populism as "evil," Einstein denounces nationalism as the "measles of mankind" or Macron simultaneously censures both populism and nationalism as a "leprosy" infecting contemporary Europe; they mistakenly conflate the entire concepts of populism and nationalism with one particular subgenus - intense and exclusionary. Such populisms and nationalisms have indeed fostered discrimination, racism, chauvinism, and violence against minorities. But inclusionary populisms and nationalisms of some intensity have also proven to be constructive forces that can widen the membership and socio-economic and political access of minorities.

Here, it is useful to clarify that irrespective of its level of inclusion, populism has been argued as containing the "seeds" of certain authoritarian tendencies (Abts and Rummens 2007; Levitsky and Loxton 2013; Müller 2016). These include the subversion of institutions, the personalization of politics, and the branding of political opponents as enemies, which shrinks the space for dissent and compromise and increases polarization (Mudde and Kaltwasser 2012). But an inclusive, intense variant of populism can also give voice to, mobilize, and represent marginalized groups and, in doing so, strengthen democracy (Moffitt 2016; Laclau 2005). Across Europe, potent inclusive nationalisms drove the establishment of liberal democracies that offered unprecedentedly equal incorporation to lower-status groups who had hitherto been shut out from the "high culture' of monarchies (Greenfeld 1992; Kymlicka 2015; Nairn 1977). Over two and a half centuries later, in the wake of the Second World War, they fueled the foundation of redistributive welfare states (Titmuss 1958; Burke 1985). Similarly, across Asia and Africa from the 1940s to the 1970s, 
powerful, inclusive nationalisms fueled struggles for independence from colonial rule and paved the way for the foundation of secular, democratic states. ${ }^{11}$

\section{Part 2: When Populism Meets Nationalism}

What does it mean for populism and nationalism to intersect? As brought out in Part 1 , populism and nationalism are analytically intertwined but are distinct phenomena. When we speak of their intersection, it is thus not of a theoretical intermingling but of specific empirical instances of their co-presence. We can examine this convergence across each of the units of analysis that both manifest in. For example, at an individual level, people can hold both populist and nationalist attitudes (Oliver and Rahn 2016). But the intersection is more meaningfully seen at a mobilizational level.

Movements and/or parties fighting for territorial sovereignty, and thus seen as nationalist, can, for example, have a highly personalized leadership and a loud, "low," "bad mannered" tactical repertoire. The adversaries against whom they frame their opposition in nationalist terms might also be economic and/or cultural elites, as was the case for the movements against monarchies in Europe and colonial rulers across Asia and Africa. Here, however, I restrict the scope of nationalist populism to a more self-conscious meeting. To the purposeful, explicit, and consistent framing of "us" as at once virtuous toiling underdogs and fellow nationals, and "them" as both elites and non-nationals, I operationalize this as populist leaders' featuring of the language, aesthetics, and emotions of nationalism in their public pronouncements.

My decision to use these semantics is rooted in an important, if implicit, distinction between populism and nationalism. Leaders and mobilizations for territorial sovereignty that scholars would thus classify as nationalist can certainly take on the discursive repertoire of populism. Indeed, leaders signal their populism in their dress, manners, and/or their personal stories. ${ }^{12}$ But inasmuch as the appellation is purely scholarly, it is rare to find nationalist leaders, movements, or parties explicitly declaring themselves "populist."13

On the other hand, populist leaders, movements, and parties do unequivocally proclaim themselves "nationalist." Trump and Modi are prominent examples from

\footnotetext{
${ }^{11}$ To complete the discussion of the quadrants in Table 2, on the bottom-left, when populism and nationalism are inclusive but not intense, they will have progressive goals but are less likely to achieve them. In the top-left quadrant, when populism and nationalism are of both low intensity and inclusiveness, they will have goals that only benefit a narrowly defined "us," but also less fuel for the attainment of such exclusively defined projects.

${ }^{12}$ For example, Modi regularly emphasizes his humble origins as the son of a tea seller (Varshney 2019a). Thailand's Thaksin and Orbán in Hungary both styled themselves as "men of "the people" by switching their suits for "unbuttoned," and "checkered" shirts (Moffitt 2015: 300; Palonen 2018).

${ }^{13}$ Some populist leaders do, however, embrace and "take pride" in being labelled populist (Bell et al. 2018; Barigazzi 2018).
} 
the contemporary crop of populists. But Latin American populist leaders have also actively aligned themselves with national heroes and narratives — from Perón's styling himself as General San Martín, the leader of Argentina's independence; Chávez's projection of himself as a successor to Simón Bolívar and his project of "national and continental liberation" (de la Torre 2017: 9); or Morales' presenting himself as the "reincarnation" of Túpac Katari, continuing his "cultural democratic" revolution to "decolonize" the state and restore Tahuantinsuyo (the Inca empire) (Marston and Kennemore 2019).

Conceptualized as such, the coming together of populism and nationalism is, like populism and nationalism themselves, also a matter of degree. Why populist leaders adopt nationalism, and to what extent, is an important question for further research (De Cleen and Stavrakakis 2020). ${ }^{14}$ Here, I examine what happens when they do.

Building on part 1, I focus on cases of intense nationalist populism and their consequences around the us-them boundary. As the confluence of populism and nationalism, nationalist populism has two categories of outsiders by definition - elites and non-nationals. How inclusively nationalist populists frame their boundaries determines whether subordinate groups are seen as "us" or "them." Following my framing of nationalist populism as populists evoking nationalism, whether nationalist populists symbolically include subordinate groups within their "us" is determined by the inclusiveness of populism, which in turn stems, as discussed in the previous section, from their underlying ideology. Ceteris paribus, relative to populism, nationalist populism deepens the antipathy and discrimination against those beyond and improves the life chances for those within its boundaries. ${ }^{15}$

I locate this "turbo-charge" to nationalist populism's fusing of the moral frame of populism with the affective power of nationalism. Nationalism is not only the legitimating ideology of political rule in our post-Westphalian global system, it is also a powerful individual identity with the unique potential to thread us simultaneously to our history, culture, homeland, and to our descendants. As such a trans-generational, territorial presence, nationalism defines our sense of self. As enemies of the nation, nationalist populists' outsiders thus present an existential threat, to the past, to the future, and to one's own self and warrant, as I show in part 2a, heightened antipathy.

But inasmuch as nationalist populism amplifies the negative consequences for those outside its borders, it also boosts the positive consequences for the "us," which in the case of inclusive nationalist populisms, also incorporate minorities. Studies building on the Common Ingroup Identity Model in social identity theory have shown that when members of previously excluded groups, such as minorities and/ or immigrants, are brought into a superordinate, encompassing national "we," they gain access to the powerful benefits of national solidarity.

\footnotetext{
${ }^{14}$ Here, it is important to flag that because exclusionary, right-leaning populists define the people in cultural, ethnic terms, they teeter closer to (an ethnic/exclusionary idea of) the nation than their inclusive, left counterparts.

15 This is why the empirical cases that Mudde and Rovira Kaltwasser (2013) select to exemplify both inclusionary left populism - Evo Morales in Bolivia and Hugo Chávez in Venezuela — and exclusionary right populism — Austria's Jörg Haider and Jean-Marie Le Pen in France — are in fact all nationalist populists.
} 
Following social psychological research, national membership is an important source of security, validation, and self-worth (Tamir 2019; Miller 1995b). This is a universal process, but because status is an especially scarce resource for marginalized groups such as ethnic minorities, immigrants, and the poor, they stand to gain more from their symbolic inclusion into the nation (Charnysh et al. 2015). Further, minorities within the fold of the nationalist populist "us" benefit from the ethical commitments reserved for those bound by ties of national solidarity. Nationalism forges a "linked fate," which motivates mutual obligations among fellow nationals (Tamir 1995; Miller 1995b). Leaders bound by national solidarity have been shown to be more likely to put in place policies for the welfare of co-nationals (Singh 2015). Nationalist populist leaders are thus more likely to prioritize the wellbeing of minorities when they are included within national boundaries.

\section{Part 2a: Increased Hostility and Discrimination Towards "Them"}

\section{Non-Nationals}

Nationalist populists charge inter-national boundaries with moral animus. Inter-state competition takes on overtones of a cosmic showdown between good and evil. As brought out by the current crop of nationalist populists, exemplified by Trump, international rivals are seen as representing malevolent enemies. Multilateral alliances and institutions such as the UN, IMF, and EU are denounced as "cosmopolitan, decadent, alien and anti-national influences" (Halikiopoulou et al. 2012: 510). The "looming threat of "global governance"" endangers the very existence of the nation (Stavrakakis et al. 2017: 24). Trade policy becomes a moral crusade with "my country first; better and over all others."

\section{Elites}

Nationalist populism also sharpens internal borders. Elites, the definitional bête noire of populists, are now also condemned as "traitors" — "un-American" for Trump, "anti-national" and "seditious" for Modi, and "Poles of the worst sort" for Kaczyński. As further evidence of the "treason" of these domestic elites, they are linked to foreign interests. For Perón, local oligarchs were "partners of colonialism" who revered "a [European] 'civilization' embodied in alien cultural patterns" (Filc 2015: 273). Chávez ridiculed opponents as "little Yankees" and "lackeys of imperialism" (de la Torre 2017: 7; Hawkins 2009: 1044). For exclusionary nationalist populists, elites' cultural distance from the heartland is also a measure of their cultural proximity to global influences. Le Pen's "French patriots" and Trump's "American nationalists" are pitted against "globalists," an "all-purpose term of abuse" for elites (Boot 2017).

This portrayal allows nationalist populist leaders to frame opposition from these elites as a plot against the nation. Chávez, for example, declared that it is not "about pro-Chávez against the anti-Chávez...but the patriots against the enemies of the homeland" (Zúquete 2008: 105). A few decades earlier in Argentina, Perón was 
pronounced "the Homeland". Peronism was declared the only way to "feel Argentinian" (de la Torre 2017: 3), and any oppositon to Perón was described as a conspiracy against Argentina.

This framing of elites as a "fifth column" sets the stage for their economic and political discrimination: from Chávez's seizing the assets of Venezuelan businesses (Jones 2008) to Modi's restriction of foreign financing of Indian NGOs, and Orbán's expulsion of Soros-funded institutions, including the Central European University. Italy, Hungary, and Poland have all discouraged the political participation of the hundreds of thousands of their "pro-EU, cosmopolitan leaning" citizens who live and work in another EU country (Fubini 2020). Under Marie Le Pen's proposal to ban dual citizenship from outside the EU, French Jews would need to choose between their French (or Israeli) citizenship (Goldhammer 2015: 139). The Indian government has arrested and brought sedition and conspiracy charges against "treasonous" intellectuals, lawyers, and activists, including climate activists (Menon 2021). Further, the atmosphere of heightened hostility against "anti-national" elites and reduced likelihood of legal repercussions have encouraged attacks by vigilantes, including violence against dissenting journalists (Alam 2020).

\section{Minorities}

I now move from the consequences of the intensity of nationalist populism to the implications of its inclusiveness. Exclusive nationalist populist boundaries coincide with dominant ethnic groups who come to stand in for the nation - Hindus in India; White Christians across Europe and in the USA. Hard-working and law-abiding, such "true natives" are distinguished from minorities who are presented as at once a parasitic underclass and urgent existential threat. In the USA, for example, Trump consistently vilified ethno-racial minorities as "lazy," as criminals and terrorists with suspect loyalty to the USA, who should "go back" to the countries they came from (Cobb 2019). Trump and exclusionary nationalist populists across Europe also dehumanized immigrants and refugees as "rapists," "animals," "termites," vectors of disease, embedded in crime cartels, "invading" national borders, and posing a "security threat" (Jenne 2018: 550; Bieber 2018: 532).

This framing lays the groundwork for exclusionary nationalist populists' heightened discrimination against and hostility to minorities. Nationalist populists across Europe have presented the welfare state as a precious "national resource" strained by globalization and immigration. The maintenance of welfare benefits for a country's "real people" requires, they argue, the exclusion of free-riding "aliens" — defined across the board as illegal immigrants, but also legal immigrants - guest workers and refugees, citizens of foreign descent, and ethnic minorities, including Muslims and the Roma (Mudde 2007: 166). ${ }^{16}$ Exclusionary nationalist populist regimes in the world's two largest democracies exemplify the political disenfranchisement of minorities. The Trump and Modi regimes have both suppressed voters from minority

\footnotetext{
16 This rationale has informed proposals for tiered, "apartheid" welfare systems across France, Belgium, and Austria that restrict and, at an extreme, abolish welfare benefits for immigrants and "non-European aliens" (Mudde and Rovira Kaltwasser 2013: 160, Filc 2015: 267).
} 
communities, restricted their access to political power, ${ }^{17}$ and further targeted their citizenship and very physical presence within their territorial borders. ${ }^{18}$

The USA and India also illustrate how portraying minorities as freeloading, security threats foments popular paranoia and alters norms around public expressions of hostility to them (Bieber 2018: 535). Numerous studies linked the rise of Trump and Modi to a spike in hate crimes against minorities (Edwards and Rushin 2018: 3; Newman et al. 2020; Varshney 2019b).

\section{Part 2b: Improved Life Chances for "Us"}

I now move from a discussion of how nationalist populism amplifies the negative consequences for "them," to delineate how, by the same logic, it deepens the emancipatory consequences for the "us." I focus, in particular, on minorities and other subordinate groups who are most likely to be incorporated within the "us" when the populists who evoke nationalism are left-leaning, as is the case in Latin America (Mudde and Rovira Kaltwasser 2013).

In Argentina, when Perón evoked nationalism, he upturned established hierarchies by placing the historically marginalized "cabecita negras" at its center (Plotkin 2010). These workers from the countryside, racialized by Buenos Aires's elites for their physical characteristics (dark skin and hair) and their occupation (the dirt and grease on their overalls) became the backbone of the Peronist vision of the Argentine nation (de la Torre 2017: 3). Similarly, in Venezuela, Chávez's nationalist language prominently emphasized indigenous and Afro-Venezuelan enslaved people and their cultures (de la Torre 2017: 5). Evo Morales' refounding of Bolivia as a "plurinational" state gave pride of place to indigenous people and elevated indigenous cosmology as a new national value (Pellegrini 2016).

This symbolic inclusion within the nation is not only a powerful vehicle for providing subordinate groups a psychological sense of security and self-worth, but it also lays the ideational basis for their material and political emancipation. Seen as

\footnotetext{
17 This was reflected in the "white-ness" of Trump's White House amidst an increasingly racially diverse America (Nakamura 2019), and the declining presence of Indian Muslims, who constitute 14\% of the population, in every power center, notably the lower house of parliament where for the first time in the history of India the ruling party, Modi's BJP, has no Muslim representatives (Jaffrelot and Tillin 2017).

18 Among other actions, in the USA, Trump revoked the DACA, preventing hundreds of thousands of unauthorized immigrants, mostly Latinx youth who came to the USA as children, from legally working in the USA, and leaving DACA beneficiaries whose personal information is entered with USCIS especially vulnerable to deportation; introduced restrictions on applications for permanent residency from legal immigrants; cut the refugee cap by over $80 \%$ to the lowest in the history of the United States; instituted bans against the travel of citizens of 13 countries representing a total of 135 million people, most with significant Muslim populations. In India, the Modi regime passed the controversial Citizenship Amendment Act, which blocks Muslim asylum-seekers from acquiring resident status and, eventually, citizenship in India (Singh 2020). In addition, the regime has announced plans to institute a nation-wide registry of citizens, requiring residents to provide documentary "proof" of their citizenship. A similar list has already identified Indian-born Muslims for potential deportation in the North-eastern state of Assam.
} 
the welfare of compatriots, subordinate groups' economic and political advancement has commanded a greater degree of commitment on the part of nationalist populist leaders. In a socio-economic context very different from welfare states of Western Europe, Latin American nationalist populists have often funded anti-poverty programs through the nationalization of natural resources. This has been deeply discursively embedded in nationalism, as the rightful reclamation of precious national resources from the clutches of rapacious colonial and imperial interests. The clearest example is Evo Morales, whose inaugural presidential speech rejected "handouts" from Europe and the United States and laid out the nationalization and industrialization of Bolivia's natural resources as an escape route from chronic poverty (Kohl and Farthing 2012). Four months later, on International Workers' Day, Morales proclaimed Chaco's gas fields as the "Property of all Bolivians." 19 Similarly, Chávez portrayed his nationalization of oil, steel, telecommunications, and electric industries as an end to the "submission and betrayal of the country," a taking back of the "national patrimony" from voracious international capital "who impose conditions of poverty on the legitimate owners of natural resources" (Madrid 2008: 494). Reflecting an analogous dynamic, Perón's nationalization of the central bank, gas, public utilities, and especially the railways were described as necessary to make Argentina "socially just, politically sovereign, and economically independent" (Wright 1974: 270). Perón's purchase of the British-owned railways in 1948 symbolized "a victory over foreign imperialists" (Wright 1974: 270). A poster depicting railway nationalization proudly proclaimed "They are now ours!" (Archivo General de la Nación, cited in Adamovsky 2016: 182).

Critics have pointed to the limits of resource nationalism. Yet resource rents have worked as the nationalist populists' "simple solution" (Brienen 2016: 85) for mobilizing funds for a range of generous social policies, from cash-transfer programs in Bolivia to food security schemes in Argentina. The naming of these policies after national figures "in order to reinforce the connection with the mythic past" starkly illustrates how nationalism has boosted the left populist project of the socio-economic inclusion of subordinate groups across Latin America (Zúquete 2008: 108). Inclusive nationalist populists also instituted political reforms that amplified the "voice of the voiceless" (Mudde and Rovira Kaltwasser 2013: 161). In the 1940s, Perón famously extended the right to vote to the "women of Argentina" who were credited with "forging the nation with their tears...sacrifices...hard work and heroism" (Hammond 2011: 142). In line with his "Bolivarian Venezuelan nationalism," Chávez introduced "Bolivarian community councils" to deepen grassroots participation.

\footnotetext{
19 The Presidential Decree for the Nationalization of Hydrocarbons begins, "Considering: That after historical struggle the people have conquered at the cost of their blood the return of our hydrocarbon wealth to the hands of the nation and that it will be used to benefit the country" (cited in Kohl and Farthing 2012: 230).
} 


\section{Conclusion}

In recent decades we have witnessed the global rise of regimes that have deepened polarization and heightened hostility, discrimination, and even violence against ethnic minorities. We need greater clarity about what exactly these regimes are.

I argue that populism and nationalism are analytically distinct phenomena. But at the root of both, and also perhaps their erroneous conflation, is a separation between those who belong and those who do not. Beginning from this shared foundation of an us-them boundary, I build an original, analytical framework that draws on but also moves beyond the existing scholarship in not only juxtaposing populism and nationalism with each other but also identifying variation within each. This schema identifies the Trumps, Modis, Bolsonaros, and Orbáns of the world as cases of the ugliest of sub-types of nationalist populism — intense and exclusionary.

Today in the wake of the Covid-19 pandemic, the future of exclusionary nationalist populists appears unclear. On the one hand, their poster-child, Donald Trump, has fallen from power in the USA. But in other parts of the world, like India, exclusionary nationalist populists have consolidated their power. The broader concern is that these populist regimes have legitimized and mobilized a nationalism hostile to ethnic minorities that could outlive their political tenures (Bonikowski 2017: 547).

But nationalism exists independent of populism. It is not "owned" by exclusionary populists. Nationalism is as plastic as it is powerful. Defined inclusively, nationalism can be a creative, constructive force. These related insights from the conceptual framework presented in this article suggest that rather than seeking to overcome nationalism (Appiah 1997; Nussbaum 1996), the way forward might be instead to embrace it — to counter the exclusionary nationalism so loudly and aggressively pushed by the present crop of populists by mobilizing alternate, multicultural visions of the nation that explicitly include ethnic and other minorities.

Acknowledgements I thank Maya Tudor for conversations around nationalism; Steve Levitsky, Stathis Kalyvas, Ashutosh Varshney, and two anonymous reviewers for their incisive and helpful feedback; Arundhati Ponnapa for stellar research assistance; and James Shelton for his support. This article was completed under the aegis of the Center of Advanced Study of Behavioral Sciences at Stanford.

\section{References}

Abts K, Rummens S. Populism versus democracy. Polit Stud. 2007;55(2):405-24.

Adamovsky E. Race and class through the visual culture of peronism. In: Alberto P, Elena E, editors. Rethinking Race in Modern Argentina. Cambridge University Press; 2016.

Akkerman A, Mudde C, Zaslove A. How populist are the people? measuring populist attitudes in voters. Comp Pol Stud. 2014;47(9):1324-53.

Alam M. Attacked, arrested, left without recourse: how 2020 was for India's journalists. The Wire. 2020. Retrieved from https://thewire.in/media/journalists-arrested-press-freedom-2020. Accessed 22 Feb 2021.

Anderson B. Imagined communities: reflections on the origin and spread of nationalism. London; New York: Verso; 1991.

Appiah KA. Cosmopolitan patriots. Crit Inq. 1997;23(3):617-39. 
Arditi B. Politics on the edges of liberalism: difference, populism, revolution, agitation. Edinburgh University Press; 2007.

Armony AC, Armony V. Indictments, myths, and citizen mobilization in Argentina: a discourse analysis. Latin American Politics and Society. 2005;47(4):27-54.

Barigazzi J. New Italian PM is proud to be populist. POLITICO. 2018. Retrieved from https://www.polit ico.eu/article/new-italian-prime-minister-giuseppe-conte-is-proud-to-be-populist/. Accessed 3 Feb 2021.

Bell M, Vandoorne S, Said-Moorhouse L. Italy's Matteo Salvini says being called a populist is 'A Compliment'. CNN; 2018. Retrieved from https:/edition.cnn.com/2018/06/27/europe/matteo-salviniinterview-intl/index.html. Accessed 3 Feb 2021.

Bieber F. Is nationalism on the rise? Assessing Global Trends. Ethnopolitics. 2018;17(5):519-40.

Billig M. Banal nationalism. London: SAGE; 1995.

Bloemraad I, Kymlicka W, Lamont M, Hing LSS. Membership without social citizenship? Deservingness \& Redistribution as Grounds for Equality. Daedalus. 2019;148(3):73-104.

Bonikowski B. Ethno-nationalist populism and the mobilization of collective resentment. Br J Sociol. 2017;68:S181-213.

Bonikowski B, DiMaggio P. Varieties of American popular nationalism. Am Sociol Rev. 2016;81(5):949-80.

Bonikowski B, Halikiopoulou D, Kaufmann E, Rooduijn M. Populism and nationalism in a comparative perspective: a scholarly exchange. Nations Nationalism. 2019;25(1):58-81.

Boot M. Three cheers for globalism! Foreign Policy. 2017. Retrieved from https://foreignpolicy.com/ 2017/10/06/three-cheers-for-globalism/. Accessed 22 Feb 2021.

Brewer MB. In-group bias in the minimal intergroup situation: a cognitive-motivational analysis. Psychol Bull. 1979;86(2):307-24.

Brienen M. A populism of indignities: Bolivian populism under evo morales. Brown J World Aff. 2016;23(1):77-93.

Brubaker R. Nationalism reframed: nationhood and the national question in the New Europe. Cambridge: Cambridge University Press; 1996.

Brubaker R. Populism and nationalism. Nations Nationalism. 2019; 1-23. https://doi.org/10.1111/nana. 12522.

Brubaker R. Why populism? Theory Soc. 2017;46(5):357-85.

Brubaker R, Feischmidt M, Fox J, Grancea L. Nationalist politics and everyday ethnicity in a transylvanian town. Princeton: Princeton University Press; 2018.

Burke V. Guns or butter? War and the making of the welfare state. Ann Arbor: University of Michigan Press; 1985.

Caiani M, Graziano PR. Varieties of populism: insights from the Italian case. Ital Polit Sci Rev/Riv Ital Sci Poli. 2016;46(2):243-67.

Canovan M. Trust the people! Populism and the two faces of democracy. Polit Stud. 1999;47(1):2-16.

Castles S. Understanding global migration: a social transformation perspective. J Ethn Migr Stud. 2010;36(10):1565-86.

Charnysh V, Lucas C, Singh P. The ties that bind: national identity salience and pro-social behavior toward the ethnic other. Comp Pol Stud. 2015;48(3):267-300.

Cobb J. Donald Trump's idea of selective citizenship. The New Yorker; 2019. Retrieved from https:// www.newyorker.com/magazine/2019/07/29/donald-trumps-idea-of-selective-citizenship. Accessed 11 Mar 2020.

De Cleen B. Populism and nationalism. In: Kaltwasser CR, Taggart P, Espejo PO, Ostiguy P, editors. The Oxford Handbook of Populism; 2019. p. 342-362.

De Cleen B, Stavrakakis Y. How should we analyze the connections between populism and nationalism: a response to Rogers Brubaker. Nations Nationalism. 2020; 1-9. https://doi.org/10.1111/nana.12575.

de la Torre C. Populism and nationalism in Latin America. Javnost-Public. 2017;24(4):375-90.

Deegan-Krause K, Haughton T. Toward a more useful conceptualization of populism: types and degrees of populist appeals in the case of Slovakia. Polit Policy. 2009;37(4):821-41.

Dekker H, Malová D, Hoogendoorn S. Nationalism and its explanations. Polit Psychol. 2003;24(2):345-76.

Doob LW. Patriotism and nationalism: their psychological foundations. New Haven: Yale University Press; 1964.

Edwards GS, Rushin S. The effect of President Trump's election on hate crimes. 2018. Retrieved from https://ssrn.com/abstract=3102652. Accessed 13 Mar 2020. 
Favell A. Philosophies of integration: immigration and the idea of citizenship in France and Britain. Springer; 2016.

Filc D. The political right in Israel: different faces of Jewish populism. London: Routledge; 2010.

Filc D. Latin American inclusive and European exclusionary populism: colonialism as an explanation. J Polit Ideol. 2015;20(3):263-83.

Font N, Graziano P, Tsakatika M. Varieties of inclusionary populism? SYRIZA, Podemos and the Five Star Movement. Gov Oppos. 2021;56(1):163-83.

Fox JE, Miller-Idriss C. Everyday nationhood. Ethnicities. 2008;8(4):536-63.

Fubini F. Voter suppression comes to Europe. Project Syndicate; 2020. Retrieved from https://www.proje ct-syndicate.org/commentary/voter-suppression-in-europe-by-federico-fubini-2020-0'1. Accessed 11 Mar 2020.

Fukuyama F. The populist surge. Am Interest. 2018; 13(4). Retrieved from https://www.the-americaninterest.com/2018/02/09/the-populist-surge/. Accessed 16 Oct 2019.

Gidron N, Bonikowski B. Varieties of populism: literature review and research agenda (Harvard University Weatherhead Center for International Affairs, Working Paper, No. 13-0004). 2013. Retrieved from https://doi.org/10.2139/ssrn.2459387.

Goldhammer A. Explaining the rise of the front national: political rhetoric or cultural insecurity? Fr Polit Cult Soc. 2015;33(2):134-42.

Goode JP, Stroup DR. Everyday nationalism: constructivism for the masses. Soc Sci Q. 2015;96(3):717-39.

Greenfeld L. Nationalism: five roads to modernity. Harvard University Press; 1992.

Gustavsson G, Miller D, editors. Liberal nationalism and its critics: normative and empirical questions. Oxford University Press; 2020.

Halikiopoulou D, Vlandas T. What is new and what is nationalist about Europe's new nationalism? Explaining the Rise of the Far Right in Europe. Nations Nationalism. 2019;25(2):409-34.

Halikiopoulou D, Nanou K, Vasilopoulou S. The paradox of nationalism: the common denominator of radical right and radical left euroscepticism. Eur J Polit Res. 2012;51(4):504-39.

Hammond G. The women's suffrage movement and feminism in Argentina from Roca to Perón. Albuquerque: University of New Mexico Press; 2011.

Hawkins KA. Is Chávez populist? Measuring populist discourse in comparative perspective. Comp Pol Stud. 2009;42(8):1040-67.

Hroch M. Social preconditions of national revival in Europe: a comparative analysis of the social composition of patriotic groups among the smaller European Nations. Columbia University Press; 2000.

Huddy L. From group identity to political cohesion and commitment. In: Huddy L, Sears DO, Levy J, editors. Oxford Handbook of Political Psychology. Oxford University Press; 2013. p. 737-73.

Jaffrelot C, Tillin L. Populism in India. In: Rovira Kaltwasser C, Taggart PA, Espejo PO, Ostiguy P, editors. The Oxford Handbook of Populism. Oxford University Press; 2017. p. 179-94.

Jagers J, Walgrave S. Populism as political communication style. Eur J Polit Res. 2007;46(3):319-45.

Jenne EK. Is nationalism or ethnopopulism on the rise today? Ethnopolitics. 2018;17(5):546-52.

Jones R. Hugo Chavez calls out the food police. Time; 2008. Retrieved from http://content.time.com/ time/world/article/0,8599,1717776,00.html. Accessed 12 Mar 2020.

Jones R, Merriman P. Hot, Banal and everyday nationalism: bilingual road signs in Wales. Polit Geogr. 2009;28(3):164-73.

Katsambekis G, Stavrakakis Y. Revisiting the nationalism/populism nexus: lessons from the Greek case. Javnost-Public. 2017;24(4):391-408.

Kazin M. The populist persuasion: an American history. Cornell University Press; 1998.

Kenny PD. Populism and patronage: why populists win elections in India, Asia, and Beyond. Oxford University Press; 2017.

Kohl B, Farthing L. Material constraints to popular imaginaries: the extractive economy and resource nationalism in Bolivia. Polit Geogr. 2012;31(4):225-35.

Kosterman R, Feshbach S. Toward a measure of patriotic and nationalistic attitudes. Polit Psychol. 1989;10(2):257-74.

Kymlicka W, Banting K. 'Immigration, multiculturalism, and the welfare state. Ethics Int Aff. 2006;20(3):281-304.

Kymlicka W. Multicultural citizenship: a liberal theory of minority rights. Oxford: Clarendon Press; 1995.

Kymlicka W. Solidarity in diverse societies: beyond neoliberal multiculturalism and welfare Chauvinism. Comp Migr Stud. 2015;3(17):1-19. 
Laclau E. On populist reason. Verso; 2005.

Landler M. Brazil's Bolsonaro is the face of populism at the Davos forum. The New York Times; 2019. Retrieved from https://www.nytimes.com/2019/01/22/world/americas/bolsonaro-populist-davosforum.html. Accessed $10 \mathrm{Feb} 2021$.

Levitsky S, Loxton J. Populism and competitive authoritarianism in the Andes. Democratization. 2013;20(1):107-36.

Lieberman ES, Singh P. Conceptualizing and measuring ethnic politics: an institutional complement to demographic, behavioral, and cognitive approaches. Stud Comp Int Dev. 2012;47(3):255-86.

Madrid RL. The rise of ethnopopulism in Latin America. World Polit. 2008;60(3):475-508.

Marston A, Kennemore A. Extraction, revolution, plurinationalism: rethinking extractivism from Bolivia. Lat Am Perspect. 2019;46(2):141-60.

Mastropaolo A. Politics against democracy: party withdrawal and populist breakthrough. In" Albertazzi D, McDonnell D, editors.Twenty-First Century Populism: The Spectre of Western European Democracy. New York: Palgrave Macmillan; 2008.

Menon S. Farmer protests: India's sedition law used to muffle dissent. BBC; 2021. Retrieved from https:// www.bbc.com/news/world-asia-india-56111289. Accessed 26 Feb 2021.

Mény Y, Surel Y. Democracies and the populist challenge. Springer; 2002.

Mill JS. The collected works of John Stuart Mill. Robson JM, editor. Toronto and London: University of Toronto Press; 1991.

Miller D. Citizenship and pluralism. Polit Stud. 1995a;43(3):432-50.

Miller D. On Nationality. Clarendon Press; $1995 \mathrm{~b}$.

Moffitt B. Contemporary populism and "the people" in the Asia-Pacific Region: Thaksin Shinawatra and Pauline Hanson. In: de la Torre C, editor. The Promise and Perils of Populism: Global Perspectives. University Press of Kentucky; 2015.

Moffitt B. The global rise of populism: performance, political style, and representation. Stanford University Press; 2016.

Mudde C. Populist radical right parties in Europe. Cambridge University Press; 2007.

Mudde C, Rovira Kaltwasser C. Populism: corrective and threat to democracy. In: Mudde C, Rovira Kaltwasser C, editors. Populism in Europe and the Americas: Threat or Corrective for Democracy? New York: Cambridge University Press; 2012. p. 205-22.

Mudde C, Rovira Kaltwasser C. Exclusionary vs. inclusionary populism: comparing contemporary Europe and Latin America. Gov Oppos. 2013;48(2):147-74.

Müller JW. False flags: the myth of the nationalist resurgence. Foreign Affairs; 2019. March/April.

Müller JW. What is populism? Penguin UK; 2016.

Mummendey A, Klink A, Brown R. Nationalism and patriotism: national identification and out-group rejection. Br J Soc Psychol. 2001;40(2):159-72.

Nairn T. The break-up of britain: crisis and neo-nationalism. New Left Books; 1977.

Nakamura D. Formal and casual White House photos show distance between Trump and increasingly diverse nation. The Washington Post; 2019. Retrieved from https://www.washingtonpost.com/ graphics/2019/politics/trump-white-house-photos-lack-racial-diversity/. Accessed 11 Mar 2020.

Newman B, Merolla JL, Shah S, Lemi DC, Collingwood L, Ramakrishnan SK. The Trump effect: an experimental investigation of the emboldening effect of racially inflammatory elite communication. Br J Polit Sci. 2020; 1-22. https://doi.org/10.1017/S0007123419000590.

Nussbaum MC. For love of country? Cohen J, editor. Boston: Beacon Press; 1996.

Oliver JE, Rahn WM. Rise of the Trumpenvolk: populism in the 2016 Election. Ann Am Acad Pol Soc Sci. 2016;667(1):189-206.

Palonen E. Performing the nation: the Janus-Faced populist foundations of illiberalism in Hungary. $\mathrm{J}$ Contemp Eur Stud. 2018;26(3):308-21.

Pauwels T. Measuring populism: a quantitative text analysis of party literature in Belgium. J Elections Public Opin Parties. 2011;21(1):97-119.

Pellegrini L. Resource nationalism in the plurinational state of Bolivia. In: Haslam PA, Heidrich P, editors. The Political Economy of Natural Resources and Development: from Neoliberalism to Resource Nationalism. Routledge; 2016. p. 191-203.

Pfeffer, A. Does the political scientist who foresaw the Trump Era still believe democracy has a future? Haaretz; 2017. Retrieved from https://www.haaretz.com/us-news/.premium-does-the-scientistwho-foresaw-trump-still-believe-in-democracy-1.5454350. Accessed $14 \mathrm{Feb} 2020$.

Plotkin M. Final reflections. In: Karush M, Oscar Chamosa O, editors. The New Cultural History of Peronism. Duke University Press; 2010. p. 271-287. 
Schulte D, Singh P. How inclusive nationalism promotes freedom: religious diversity and state institutions. Paper presented at the American Political Science Association Annual Meeting, 2020. 2020.

Singh P. How solidarity works for welfare: subnationalism and social development in India. Cambridge University Press; 2015.

Singh P. The case for reclaiming Indian nationalism. Seminar; 2020; 725. Retrieved from https://www. india-seminar.com/2020/725/725_prerna_singh.htm. Accessed 1 Feb 2020.

Skey M. National belonging and everyday life: the significance of nationhood in an uncertain world. Springer; 2011.

Sniderman PM, Hagendoorn L, Prior M. Predisposing factors and situational triggers: exclusionary reactions to immigrant minorities. Am Polit Sci Rev. 2004;98(1):35-49.

Stavrakakis Y, Katsambekis G, Nikisianis N, Kioupkiolis A, Siomos T. Extreme right-wing populism in Europe: revisiting a reified association. Crit Discourse Stud. 2017;14(4):420-39.

Tamir Y. Liberal nationalism. Princeton University Press; 1995.

Tamir Y. Why nationalism. Princeton University Press; 2019.

Theiss-Morse E. Who counts as an American?: The boundaries of national identity. Cambridge University Press; 2009.

Titmuss RM. War and social policy. Essays on the Welfare State. London: George Allen and Unwin; 1958.

Tudor, M., \& Slater, D. Nationalism, authoritarianism and democracy: historical lessons from South and Southeast Asia.\&nbsp;Perspectives on Politics. 2020.

Varshney A. Modi consolidates power: electoral vibrancy, mounting liberal deficits. J Democr. 2019b;30(4):63-77.

Varshney A. The emergence of right-wing populism in India. In: Jayal NG, editor. Re-Forming India: The Nation Today. Penguin Viking Press; 2019a. p. 327-345.

Wimmer A. Ethnic boundary making: institutions, power, networks. Oxford University Press; 2013.

Wright WR. British-owned railways in Argentina: their effect on the growth of economic nationalism, 1854-1948. University of Texas Press; 1974.

Zúquete P. The missionary politics of Hugo Chávez. Latin Am Polit Soc. 2008;50(1):91-121.

Publisher's Note Springer Nature remains neutral with regard to jurisdictional claims in published maps and institutional affiliations.

Prerna Singh is Mahatma Gandhi Associate Professor of Political Science and International Studies at Brown University, with appointments in the School of Public Health and the Department of Sociology. She has studied at Princeton, Cambridge and Delhi Universities, and taught previously at Harvard University. Singh has published numerous award-winning books and articles on questions of human development, public health, ethnicity and nationalism. Her first book, How Solidarity Works for Welfare was awarded best book prizes from both the American Political Science and the American Sociological Associations. Singh has been awarded fellowships by the Center for Advanced Study of Behavioral Sciences at Stanford University, the Andrew Carnegie foundation, the American Academy of Berlin, the Harvard Academy for International and Area Studies, the University of Pennsylvania, and the American Institute of Indian Studies. Singh serves on various editorial boards, the academic advisory board of the HarvardYenching Institute, the steering committee of the Center for Contemporary South Asia at Brown, is a fellow of the Canadian Institute for Advanced Research and co-convenes the Brown-Harvard-MIT Joint Seminar in South Asian Politics. In 2021-22 Singh will serve as President of the Comparative Politics section of the American Political Science Association. 